\title{
PESANTREN: LEMBAGA PENDIDIKAN BERBASIS MASYARAKAT (Tinjauan Pasal 1 ayat 4 PP Nomor 55 Tahun 2007 Tentang Pendidikan Agama dan Pendidikan Keagamaan)
}

\section{Ulfah Rahmawati}

STAIN Kudus, Jawa Tengah, Indonesia

fabrabma@gmail.com

\begin{abstract}
Pesantren is one of the religious education institutions that have gained trust from the people of Indonesia. The position of pesantren as an educational institution, also received government recognition, as mentioned in article 1 verse 4 of PP No.55 of 2007 on Religious Education, that Pesantren or Islamic boarding school is a communitybased Islamic education institution. The concept of community-based education at its core is education from society, by society and for society. The study of this article is viewed from the aspect of law, religion, education, social and culture. In addition, the function of PP No.55 of 2007 is expected to not only be a function that is only written in the rules, but also applicable in the implementation. The existence of PP No.55 of 2007 really brings benefits, especially here in the development of pesantren as one form of community-based education institutions.
\end{abstract}

Keywords: pesantren, community-based education 


\section{Abstrak}

Pesantren merupakan salah satu lembaga pendidikan keagamaan yang telah mendapatkan kepercayaan di kalangan masyarakat Indonesia. Kedudukan pesantren sebagai lembaga pendidikan, juga mendapat pengakuan pemerintah, sebagaimana disebutkan dalam pasal 1 ayat 4 PP No.55 tahun 2007 tentang Pendidikan Agama dan Pendidikan Keagamaan, bahwa Pesantren atau pondok pesantren adalah lembaga pendidikan keagamaan Islam berbasis masyarakat. Konsep pendidikan berbasis masyarakat pada intinya adalah pendidikan dari masyarakat, oleh masyarakat dan untuk masyarakat. Adapun kajian terbadap pasal ini pesantren dillihat dari segi bukum, agama, pendidikan, sosial dan budaya. Selain itu, fungsi PP No.55 tabun 2007 tersebut dibarapkan tidak hanya menjadi suatu fungsi yang hanya tersurat dalam peraturan, akan tetapi juga aplikatif dalam pelaksanaannya. Sebingga keberadaan PP No.55 tabun 2007 ini benar-benar membawa manfaat, kbususnya di sini dalam pengembangan pesantren sebagai salab satu wujud lembaga pendidikan berbasis masyarakat.

Kata Kunci: pesantren, pendidikan berbasis masyarakat

\section{A. PENDAHULUAN}

Pendidikan menjadi tumpuan harapan bagi peningkatan kualitas Sumber Daya Manusia(SDM) Bangsa Indonesia. Pendidikan menjadi sarana bagi pembentukan intelektualitas, bakat, akhlak serta kecakapan peserta didik. Dunia pendidikan di masa depan memang dituntut untuk lebih dekat dengan realitas dan permasalahan hidup di tengah menghimpit masyarakat. Ungkapan School is mirror society (sekolah/ lembaga pendidikan adalah cermin masyarakat), seyogyanya benar-benar mewarnai proses pendidikan yang sedang berlangsung. Sebagai konsekuensinya, lembaga pendidikan harus ikut berperan aktif dalam memecahkan problem pendidikan dan kehidupan sosial.

Peluang masyarakat untuk mendapatkan pendidikan sesuai dengan kebutuhannya juga kian tersedia yaitu melalui konsep pendidikan berbasis masyarakat. Salah satu lembaga pendidikan 
yang dipercaya telah mencerminkan konsep pendidikan berbasis masyarakat adalah pesantren. Pesantren secara historis merupakan lembaga pendidikan tertua di Indonesia. Peranannya dalam sejarah perkembangan pendidikan di Indonesia tidak dapat dipandang sebelah mata.

Menurut data Kementerian Agama tahun 2001 menunjukkan jumlah pesantren di Indonesia mencapai 11.312 dengan santri sebanyak 2.737.805 orang. Pada tahun 2005 jumlah pesantren mengalami peningkatan mencapai 14.798 lembaga dengan jumlah guru 243. 738 orang dan santri 3.464. 334. Data terakhir tahun 2016 menunjukkan pesantren sebanyak 28.961 lembaga dengan santri sebanyak 4.028 .660 jiwa. Jumlah ini merupakan potensi yang banyak dan dapat menghasilkan output dan outcomes yang memiliki standar kompetensi lulusan yang tinggi jika dikelola dengan sistem yang baik.

Pesantren sebagai lembaga pendidikan berbasis masyarakat, dengan jumlah pesantren dan santri yang demikian banyak dituntut untuk dapat menjawab kebutuhan masyarakat seiring dengan tuntutan perubahan zaman, sehingga dibutuhkan manajemen dan tata kelola sistem pendidikan yang baik sehingga menghasilkan tata kelola yang baik dalam upaya meningkatkan mutu manajemen (tata kelola) pesantren ke arah yang lebih baik.

Pembahasan ini merupakan analisis terhadap makna pesantren sebagai lembaga pendidikan keagamaan Islam berbasis masyarakat, sebagaimana tersurat dalam pasal 1 ayat 4 PP No.55 tahun 2007 bahwa Pesantren atau pondok pesantren adalah lembaga pendidikan keagamaan Islam berbasis masyarakat yang menyelenggarakan pendidikan diniyah atau secara terpadu dengan jenis pendidikan lainnya. Oleh karena itu penting adanya untuk mengetahui terlebih dahulu bagaimana konsep pendidikan berbasis masyarakat? Bagaimana pesantren sebagai lembaga

${ }^{1}$ Suwendi, Penguatan Peran Pesantren, 15 Maret 2017, http://www. nu.or.id/post/read/76057/penguatan-peran-pesantren, di akses pada november 2017 pukul 09.00 
pendidikanberbasis masyarakat? dan bagaimana kedudukan pesantren sebagai lembaga pendidikan keagamaan Islam berbasis masyarakat dalam tinjauan pasal 1 PP Nomor 55 Tahun 2007 ?

\section{B. PEMBAHASAN}

\section{Konsep Pendidikan Berbasis Masyarakat}

Pendidikan berbasis masyarakat menjadi sebuah gerakan penyadaran masyarakat untuk terus belajar sepanjang hayat dalam mengatasi tantangan kehidupan yang berubah-ubah dan semakin berat. Secara konseptual, pendidikan berbasis masyarakat adalah model penyelenggaraan pendidikan yang bertumpu pada prinsip" dari masyarakat, oleh masyarakat dan untuk masyarakat". Pendidikan "dari masyarakat" artinya pendidikan memberikan jawaban atas kebutuhan masyarakat. Pendidikan "oleh masyarakat" artinya masyarakat ditempatkan sebagai subjek/ pelaku pendidikan, bukan objek pendidikan. Pada konteks ini, masyarakat dituntut peran dan partisipasi aktifnya dalam setiap program pendidikan. Adapun pendidikan"untuk masyarakat" artinya masyarakat diikutsertakan dalam semua program yang dirancang untuk memenuhi kebutuhan mereka. Secara singkat dikatakan, masyarakat perlu diberdayakan, diberi peluang dan kebebasan untuk mendesain, merencanakan, membiayai, mengelola dan menilai sendiri apa yang diperlukan secara spesifik di dalam, untuk dan oleh masyarakat sendiri. ${ }^{2}$

Pendidikan berbasis masyarakat atau community based education, disini masyarakat diberikan kesempatan untuk menyelenggarakan pendidikan. Di sisi lain peluang besar yang diberikan pemerintah hendaknya dapat dimanfaatkan masyarakat secara optimal. Pendidikan berbasis masyarakat tentunya lebih diarahkan kepada pendidikan bermutu dan sesuai pula dengan harapan masyarakat. Dengan pendidikan berbasis masyarakat

${ }^{2}$ Zubaedi, Pendidikan Berbasis Masyarakat, (Yogyakarta: Pustaka Pelajar, 2009) hlm.132 
berarti masyarakat bertanggung jawab dalam sektor pendidikan. Masyarakat juga dituntut untuk menumbuhkembangkan dan membesarkan gairah pendidikan itu sendiri. Tanpa dukungan masyarakat, maka pendidikan itu tidak ada arti apa-apa. Masyarakat merupakan garda terdepan di dalam kelangsungan pendidikan ke depan. Karenanya masyarakat diminta memberikan kontribusi nyata dalam pengembangan pendidikan, khususnya di wilayah masing-masing. ${ }^{3}$

Pendidikan dianggap berbasis masyarakat ketika tanggungjawab perencanaan hingga pelaksanaan berada di tangan masyarakat. Term berbasis masyarakat di sini menunjuk pada derajat kepemilikan masyarakat. Jika masyarakat memiliki otoritas dalam mengambil keputusan dan menentukan tujuan pendidikan, sasaran, pembiayaan, kurikulum, standar dan ujian, kualifikasi guru, persyaratan peserta didik, tempat penyelenggaraan dan lainlain berarti program pendidikan tersebut berbasis masyarakat. Sebaliknya, jika semuanya ditentukan oleh pemerintah, maka disebut berbasis pemerintah( state-based education). Atau jika semuanya ditentukan oleh sekolah, maka disebut pendidikan berbasis sekolah( school-based education).

Model pendidikan berbasis masyarakat untuk konteks Indonesia kini semakin diakui keberadaannya melalui UU SISDIKNAS Nomor 20 tahun 2003 dalam bab peran serta masyarakat dalam pendidikan ${ }^{4}$. Dalam perkembangannya, Community-based education diharapkan menjadi salah satu fondasi dalam mewujudkan masyarakat madani.

${ }^{3}$ Isjoni, Pendidikan sebagai Investasi Masa Depan,( Jakarta: Yayasan Obor Indonesia,2006), hlm.14

${ }^{4}$ Undang-Undang Republik Indonesia Nomor.20 Tahun 2003 tentang Sistem Pendidikan Nasional pasal 55, UU guru dan Dosen dan UU SISDIKNAS ( Sistem Pendidikan Nasional) UU RI No. 20 Th.2003, (Jakarta: Asa Mandiri, 2006), hlm. 74 


\section{Pesantren Sebagai Lembaga Pendidikan Berbasis Masyarakat}

Pelaksanaan pendidikan berbasis masyarakat di Indonesia sebenarnya bukanlah hal yang baru. Sudah lama pendidikan berbasis masyarakat tumbuh dan berkembang, bahkan tetap eksis sampai saat ini, hanya saja istilahnya berbeda. Bentuk pendidikan berbasis masyarakat yang masih ada dan tetap eksis sampai saat ini, bahkan menjadi model pendidikan yang cukup menjadi trend adalah madrasah dan pesantren.

Pada perkembangannya pendidikan berbasis masyarakat mewujud dalam bentuk lembaga-lembaga kursus yang berada di bawah binaan Pendidikan Luar Sekolah(PLS). Akan tetapi, lembaga-lembaga ini seakan lebih berorientasi kepada bisnis (profit oriented) tanpa mengindahkan segi sikap, moral dan agama yang justru sangat dibutuhkan di masa sekarang. Oleh karena itu, implementasi pendidikan berbasis masyarakat yang benar-benar menyiapkan manusia terdidik secara utuh, baik yang bersifat intelektual, sikap moral, dan agama sebagai dasar hanyalah pesantren atau sekolah yang berbasis madrasah. ${ }^{5}$

Seiring dengan perjalanan bangsa kita, ketika lembagalembaga sosial yang lain belum berjalan secara fungsional maka pesantren telah menjadi pusat kegiatan masyarakat dalam belajar. Tegasnya, pesantren merupakan lembaga pendidikan yang unik, tidak saja karena keberadaannya yang sudah sangat lama, tetapi juga karena kultur, metode dan jaringan yang diterapkan oleh lembaga pendidikan agama ini yang khas.

Pesantren juga memiliki jaringan sosial yang kuat dengan masyarakat dan dengan sesama pesantren karena sebagian besar pengasuh pesantren tidak saja terikat pada kesamaan pola pikir, paham keagamaan, namun juga memiliki hubungan kekerabatan

5 Sam M Chan, Analisi SWOT: Kebijakan Pendidikan Era Otonomi Daerah,(Jakarta: PT RajaGrafindo Persada, 2007) hlm,121 
yang cukup erat. ${ }^{6}$ Dinamika lembaga pendidikan Islam yang relatif tua di Indonesia ini tampak dalam beberapa hal, seperti ${ }^{7}$ pertama, peningkatan secara kuantitas terhadap jumlah pesantren. Kedua, kemampuan pesantren untuk selalu hidup di tengah-tengah masyarakat yang sedang mengalami berbagai perubahan. Secara sosiologis, ini menunjukkan bahwa pesantren masih memiliki fungsi nyata yang dibutuhkan masyarakat.

\section{Analisis Pesantren Sebagai Lembaga Pendidikan Berbasis Masyarakat( Tinjauan Pasal 1 ayat 4 PP Nomor 55 Tahun 2007 Tentang Pendidikan Agama Dan Pendidikan Keagamaan)}

\section{a. Analisis Hukum}

Pada analisis hukum ini menggunakan perspektif analisis histori. Menurut Noourouzzaman Shiddiqi, dalam anlisis histori selalu memerlukan tiga unsur pokok yaitu pertama, proses asal-usul(origin), kedua, perubahan(change) dan ketiga, perkembangan (develompent $)^{8}$. Pesantren yang secara historis yang sudah ada 700 tahun yang lalu (abad 13), baru secara regulatif terformalkan setelah ada Undang-Undang No. 20 th 2003 dan PP No. 55 th 2007 tentang pendidikan agama dan pendidikan keagamaan. Kata pesantren terakomodir, tersurat, terlihat jelas, dan ada; bagaimana dan untuk apa pesantren itu berada. Dengan diterbitkannya PP No.55 tahun 2007 tentang pendidikan agama dan pendidikan keagamaan, eksistensi pesantren mendapat legitimasi hukum sebagai lembaga pendidikan keagamaan Islam yang berbasis masyarakat.

Eksistensi pesantren sebagai lembaga pendidikan keagamaan di dunia pendidikan Indonesia hingga diterbitkannya

${ }^{6}$ Zubaedi, Pendidikan Berbasis Masyarakat, hlm.141

7 Khozin, Jejak-Jejak Pendidikan Islam di Indonesia,( Malang: Universitas Muhammadiyah Malang, 2006), hlm.107

8 Nourouzzaman Shiddiqi, Jeram-jeram Peradaban Muslim,( Yogyakarta:Pustaka Pelajar,1996), hlm.12 
PP ini tidak lepas dari perjalanan panjang pasang surut kebijakan pemerintah dari masa ke masa. Pada UU SISDIKNAS Nomor 2 Tahun 1989, posisi pendidikan keagamaan sebagai Pendidikan Luar Sekolah. Sehingga konsekuensi logis dari kebijakan ini jelas menjadikan lembaga keagamaan tidak mendapatkan perlakuan sejajar dari pemerintah, terutama dalam hal hak untuk mendapatkan anggaran.

Kehadiran UU SISDIKNAS Nomor 20 Tahun 2003, telah merubah kondisi itu. Dengan disahkannya UU SISDIKNAS ini, pendidikan keagamaan memiliki kedudukan yang sejajar dengan pendidikan umum, kejuruan, akademik. ' Pesantren merupakan salah satu bentuk pendidikan keagamaan yang diselenggarakan pemerintah dan atau kelompok mayarakat ${ }^{10}$. Peran serta masyarakat dalam pendidikan yang salah satunya diwujudkan melalui pendidikan berbasis masyarakat ${ }^{11}$.

Mengingat pentingnya penjabaran lebih rinci untuk mempermudah pelaksanaan secara tehnis sebagai panduan di lapangan,maka tepatnya pada tanggal 5 oktober 2007, produk hukum yang berupa Peraturan Pemerintah(PP) Nomor 55 tahun 2007 tentang pendidikan agama dan pendidikan keagamaan, ditetapkan oleh pemerintah yang dalam pengelolaannya sesuai dengan PP 55 Tahun 2007.

PP No.55 Tahun 2007 tentang Pendidikan agama dan Pendidikan Keagamaan, terdapat beberapa pasal yang menyebutkan kata pesantren dalam teksnya. Pasal 1 (pengertian pesantren), Pasal 8 - pasal 14 dan kemudian pasal 26. Beberapa pasal tersebut menjelaskan tentang pesantren, pendidikan keagamaan dengan segala syarat dan ketentuannya.

${ }^{9}$ Undang-Undang Republik Indonesia Nomor.20 Tahun 2003 tentang Sistem Pendidikan Nasional BAB VI tentang jalur, jenjang dan jenis pendidikan, pasal 15, UU guru dan Dosen dan UU SISDIKNAS (Sistem Pendidikan Nasional) UU RI No. 20 Th.2003, hlm. 57

\footnotetext{
${ }^{10}$ Ibid, pasal 30, hlm.63

${ }^{11}$ Ibid, pasal 55 ,hlm.74
} 
PMA RI Nomor 3 Tahun 2012, Tentang Pendidikan Keagamaan Islam. Peraturan ini merupakan peraturan yang dikukuhkan pada tanggal 23 Februari 2012 di Jakarta oleh Menteri Agama RI, Surya Darma Ali. Dalam PMA ini hanya khusus menjelaskan diniyah dan pesantren dengan segala tata aturan pedoman penyelenggaraannya.

Beberapa produk hukum yang melegitimasi keberadaan pesantren hingga kemudian memiliki kekuatan yuridis. Diharapkan dengan produk hukum tersebut eksistensi pesantren sebagai lembaga pendidikan mendapatkan kesederajatan dengan lembaga pendidikan lainnya. Pandangan pemerintah yang berbeda akan pendidikan umum dan pesantren sebagai pendidikan keagamaan tidak terjadi. Karena peran serta pesantren dalam sejarah perkembangan pendidikan Indonesia sangatlah besar dan terbukti. Pesantren juga telah berperan aktif dalam pendidikan sebagaimana rumusan fungsi dan tujuan pendidikan. ${ }^{12}$

b. Analisis Agama

Pesantren sebagai lembaga pendidikan Islam, menampakkan secara lebih jelas bahwa prinsip - prinsip pendidikannya bersifat teosentris. Dimana orientasi pendidikan pesantren memusat pada sikap taqarrub(mendekatkan diri kepada Allah dengan keteguhan dan ketaatan beribadah serta melaksanakan ajaran-ajaran agama) dan sikap tahasun(melaksanakan sikap kesalehan individual maupun kesalehan sosial). ${ }^{13}$

Pesantren pada dasarnya adalah sebuah lembaga pendidikan keagamaan Islam, walaupun ia mempunyai fungsi yang juga tidak kalah penting dengan fungsi pendidikan tersebut. Pesantren merupakan lembaga pengembang nilai moral-spiritual, informasi, komunikasi timbal balik secara kultural dengan masyarakatnya. Dalam rumusan Azzumardi Azra, pesantren telah memainkan tiga peranan: transmission of Islamic knowledge (penyampaian ilmu-

${ }^{12} \mathrm{Ibid}$, pasal 3, hlm.53.

${ }^{13}$ Mujamil Qomar, Pesantren dari Transformasi Metodologi Menuju Demokratsasi Institusi,( Jakarta: Erlangga, 2006 ), hlm.65. 
ilmu keislaman), maintenance of islamic tradition(pemeliharaan tradisi Islam) dan reproduction of ulama(pembinaan calon ulama). ${ }^{14}$

c. Analisis Politik

Kebijakan-kebijakan pemerintah tidak pernah lepas dari unsur politik. Hegemoni (kekuasaaan). Menurut Toto Suharto Pendidikan kritis (critical pedagogy) selalu menegaskan bahwa pendidikan bersifat politis, artinya setiap kebijakan pendidikan yang dibuat pemerintah selalu mengandung kepentingan politis untuk melanggengkan kekuasaannya. Pendidikan dalam pendidikan kritis tidak bersifat netral, tetapi memihak pada kepentingan dan ideologi pembuatnya yang dalam hal ini adalah pemerintah. ${ }^{15}$

Secara hegemonik, negara menguasai lembaga politik dan sosial kemasyarakatan dalam rangka menarik massa agar berada dalam spektrum kebijakan dan kekuasaan pemerintah. Dari sinilah, pesantren yang semula independen dari ranah politik menjadi termobilisasi demi kepentingan penguasa. Mobilisasi di sini dipahami, sebagai pengakomodasian kepentingan pesantren demi mendukung sepenuhnya rekayasa pengembangan pemerintah. ${ }^{16}$

d. Analisis Pendidikan

Aktualisasi pendidikan yang baru dengan prinsip-prinsip yang disesuaikan dengan tuntutan kebutuhan dan perkembangan zaman sekarang, yaitu partisipasi masyarakat di dalam mengelola pendidikan (community), demokratisasi proses pendidikan, sumber daya pendidikan yang profesional, dan sumber daya yang memadai. ${ }^{17}$ Tanggungjawab pendidikan tidak lagi dipikul hanya

14 Azyumardi Azra, Esei-Esei Inteletual Muslim Pendidikan Islam, Jakarta:Logos Wacana Ilmu,1998) hlm.89.

15 Toto Suharto, Pesantren Persatuan Islam(1987-1997) dalam Perspektif Pe didikan Berbasis Masyarakat, Disertasi (Yogyakarta:PPs UIN SUKA),hlm.

16 Ahmad Ali Riyadi, Pesantren dalam bingkai Politik Birokrasi Pendidikan Islam di Indonesia, Vol.23 No.1 Januari 2012, hlm.93.

17 H.A.R Tilaar, Paradigma Baru Pendidikan Nasional,(Jakarta:Rineka 
oleh pemerintah, tetapi juga dibebankan kepada masyarakat. Maksudnya, pemerintah dan masyarakat sama-sama bertanggung jawab pada segala hal yang berkaitan dengan pendidikan. Pemerintah dan masyrakat harus memiliki kepedulian yang sama terhadap mutu dan keberhasilan pendidikan. ${ }^{18}$

Legitimasi pemerintah terhadap pesantren sebagai lembaga pendidikan, tentu akan juga membawa perubahan pada keberadaan pesantren itu sendiri. Melalui PP ini pemerintah memberikan kewenangan kepada masyarakat untuk menyelenggarakan pendidikan keagamaan.

Pengaruh pendidikan pesantren sangat kuat mengakar pada masyarakat kita, terbukti semakin banyak pesantren yang bermunculan sebagai perwujudan penyelenggaraan pendidikan keagamaan. Menurut data Kementerian Agamatahun 2016 menunjukkan pesantren sebanyak 28.961 lembaga dengan santri sebanyak 4.028.660 jiwa. Jumlah ini merupakan potensi yang banyak dan dapat menghasilkan output dan outcomes yang memiliki standar kompetensi lulusan yang tinggi jika dikelola dengan sistem yang baik.

Selain itu, kecenderungan yang kuat bahwa santri membutuhkan ijazah dan menguasai bidang keahlian, atau ketrampilan tertentu sehingga dapat mengantarkannya menguasai lapangan kehidupan. Semua merupakan dampak dari tuntutan perubahan isasi kelembagaan pendidikan. Isasi di dunia dakwah dan pendididikan Islam kontemporer, yang tidak hanya mengubah basis sosio-kultural dan pengetahuan santri semata, melainkan juga beriimbas pada masyarakat Islam secara keseluruhan.Pondok pesantren sekarang ini pada umumnya telah mengalami perubahan dari dampak modernisasi. Menjadikan santri memiliki banyak sumber-sumber belajar baru, dan semakin

Cipta,2002), hal.

${ }^{18}$ Sam M.Chan, Tuti T. Sam, Analisi SWOT: Kebijakan Pendidikan Era Otonomi Daerah, hlm.115. 
tingginya dinamika komunikasi antara sistem pendidikan pondok pesantren dan sistem yang lain. ${ }^{19}$

Terkait dengan pesantren sebagai lembaga pendidikan berbasis masyarakat, kemandirian pesantren dengan segala kebijakan yang berkaitan dengan penyelenggaraan pendidikan, dari tata aturan, manajemen, kurikulum, evaluasi, pendanaan yang dikelola secara mandiri. Perkembangan pendidikan saat ini memang menuntut pendidikan di pesantren juga terbuka untuk menerima perubahan perkembangan ini. Beberapa wacana dan telah banyak pesantren yang melakukan inovasi, transformasi,kurikulum, sistem pembelajaran, penyelenggaraan pendidikan. Akan tetapi semua itu jangan sampai mengaburkan atau memudarkan karakteristik pesantren.

Pembaharuan pendidikan yang dilakukan oleh pesantren selalu didasari oleh kaidah: "Al-Mubafazhatu Ala al-Qodim asShalih, Wal Akhdzu bil jadid al-Ashlah( melestrikan nilai-nilai lama yang baik dan mengambil nilai-nilai baru yang lebih baik). Kaidah ini telah menjadi acuan yang cukup kuat di dalam kultur pesantren, dan sekaligus menjadi pegangan bagi upaya-upaya pembaharuan yang dilakukan oleh masyarakat santri yang tersebar di Indonesia.Di mana pendidikan di pesantren harus juga mengikuti perkembangan zaman, tanpa harus terperosok dan kehilangan jati diri pesantren itu sendiri. Hal ini penting karena ilmu pengetahuan tidak statis, selalu bergerak dinamis dan meningkat tiap hari.

\section{Analisis Sosial}

a.

Pesantren sebagai lembaga pendidikan berbasis masyarakat, tentunya memiliki hubungan yang sangat erat dengan dimensi sosial kemayarakatan. Bagaimana peran pesantren dituntut untuk menjawab kebutuhan dan tuntutan masyarakat. Karena bertolak pada prinsip pendidikan berbasis masyrakat dimana

19 Nurotun Mumtahanah, Pengembangan Sistem Pesantren dalam Menin katkan Profesionalisme Santri, Al-Hikmah Jurnal Studi Keislaman, 2015, Vol.5(1), hlm.56. 
masyarakat menjadi subjek pendidikan. Penyelenggaraannya pun juga seharusnya disesuaikan dengan kebutuhan masyarakatnya. Sebagaimana juga menurut Amin Haedari, bahwa pesantren juga sebagai laboratorium sosial kemayarakatan. ${ }^{20}$

Peran pesantren dalam sosial kemasyarakatan, dimana pendidikan yang diberdayakan untuk umat. Pesantren sebagai center decision terhadap persoalan-persoalan agama yang ada di masyarakat dibutuhkan oleh masyarakat dalam menghadapi tuntutan zaman. Pola kemitraan pesantren dengan masyarakat juga terwujud melalui kegiatan pengembangan masyarakat yang dilakukan pesantren. Sebagaimana telah dilakukan oleh salah satu pesantren di Pati Jawa Tengah yaitu Pesantren Maslakhul Huda di bawah kepemimpinan KH Sahal Mahfudz yang menggulirkan Fiqh Sosial.

Pesantren yang benar-benar mengimplementasikan prinsip pendidikan berbasis masyarakat secara utuh nampaknya saat ini belum terwujud pada semua pesantren. Apalagi prinsip bahwa pesantren ini didirikan atas kehendak masyarakat karena pada umumnya penyelenggaraan, pengelolaan dan kebijakan pesantren nyatanya lebih banyak dibuat atas dasar kepentingan pengelola pesantren tersebut. Anggapan masyarakat bahwa pesantren terkesan eksklusif juga tidak sepenuhnya salah, karena pada praktiknya ada pesantren yang tidak mengenal dan memasyarakat dengan masyarakat sekitarnya, sehingga seolah ada gap yang memisahkan antara kehidupan pesantren dan .masyarakat.

Tipologi pesantren yang memang berdiri, berada, dan berkembang atas partisipasi masyarakat nampaknya lebih cenderung pada tipologi pesantren tradisional yang berada di pedesaan. Senada dengan hal tersebut Nurcholis Madjid dalam bukunya Bilik-Bilik Pesantren, mengungkapkan bahwa pesantren dengan sistem dan karakter tersendiri telah menjadi bagian integral dari suatu institusi sosial -masyarakat, khususnya pedesaan. Meski

${ }_{20}^{\text {H.M.Amin }}$ (Jakarta:IRD,2004),hlm.177.
Haedari,dkk, Masa depan Pesantren,


mengalami pasang surut dalam mempertahankan eksistensi dan misinya, namun sampai kini pesantren tetap survive. ${ }^{21}$

Pesantren dituntut mampu merumuskan konsep pengembangan ajaran Islam sebagai tatanan sosial, bukan hanya lembaga legalistik yang bersifat hitamputih. Oleh karena itu untuk mempermudah pesantren menjalankan peranannya dibutuhkan kemampuan antisipatif dan keterbukaan. Keterbukaan akan menumbuhkan sikap lentur (fleksibel) yang akomodatif. Bentuk dari keterbukaan ini berupa pesantren dengan tulus ikhlas bersedia menerima masukan positif, konstruktif, dan inovatif yang berasal darimanapun. Kemudian pesantren juga harus bersedia mengakui serta mengoreksi kelemahan yang menimpanya untuk dicarikan solusinya ${ }^{22}$.

e. Analisis Budaya

Pendidikan keagamaan pada umumnya diselenggarakan oleh masyarakat sebagai perwujudan pendidikan dari, oleh dan untuk masyarakat. Pesantren merupakan salah satu perwujudan lembaga pendidikan keagamaan Islam yang berbasis masyarakat yang keberadaanya jauh sebelum Indonesia merdeka, bahkan sejak Islam datang di Indonesia. Oleh karenanya hal ini menjadi akar budaya bangsa agama yang disadari merupakan bagian yang tak terpisahkan dalam pendidikan. Sebagaiman juga dinyatakan oleh Ki Hajar dewantara yang pernah mencita-citakan model pesantren sebagai sistem pendidikan Indonesia. Menurutnya, selain sudah lama melekat dalam kehidupan di Indonesia, model pesantren juga merupakan kreasi budaya Indonesia, setidaktidaknya di Pulau Jawa, yang patut untuk dipertahankan dan dikembangkan ${ }^{23}$. Perspektif historis menempatkan pesantren

21 Nurcholis Madjid, Bilik-Bilik Pesantren,(Jakarta:Paramadina,1997), hlm.124.

${ }^{22}$ Mujamil Qomar, Pesantren dari Transformasi Metodologi Menuju Demokrat sasi Institusi ,hlm. 75 .

${ }^{23}$ Nurcholish Madjid, , Bilik-Bilik Pesantren, hlm.121. 
Pesantren: Lembaga Pendidikan Berbasis Masyarakat....

pada posisi yang cukup istimewa dalam khazanah perkembangan sosial - budaya di Indonesia.

\section{Fungsi PP No.55 Tahun 2007 Terhadap Pengembangan Pesantren ke Depan}

Pesantren merupakan salah satu lembaga pendidikan tertua di Indonesia yang memiliki kontribusi penting dalam mencerdaskan kehidupan bangsa. Lembaga ini layak diperhitungkan dalam pembangunan bangsa dibidang pendidikan, keagamaan, moral, dan juga sosial kemasyarakatan. Dilihat secara historis, pesantren memiliki pengalaman luar biasa dalam membina, mencerdaskan, dan mengembangkan masyarakat. Bahkan, pesantren mampu meningkatkan perannya secara mandiri dengan menggali potensi yang dimiliki masyarakat di sekelilingnya.

Pembangunan sumber daya manusia(SDM) tidak hanya menjadi tanggung jawab pemerintah saja, akan tetapi juga menjadi tanggung jawab semua komponen masyarakat, termasuk dunia pesantren. Karena itu, sudah semestinya pesantren yang telah memiliki nilai historis dalam membina dan mengembangkan SDM ini terus didorong dan dikembangkan kualitasnya. Pengembangan dunia pesantren ini harus didukung secara serius oleh pemerintah. Hal ini juga sudah terintegrasi dalam sistem pendidikan nasional(sisdiknas) dan secara terinci dijelaskan dalam PP No 55 Tahun 2007. Mengembangkan peran pesantren dalam pembangunan merupakan langkah strategis dalam membangun pendidikan.

PP Nomor 55 Tahun 2007, merupakan peraturan pemerintah yang lahir untuk memperjelas amanat UU sisdiknas tahun 2003, dalam PP ini juga memperjelas fungsi dan tujuan pesantren sebagai bagian yang tak terpisahkan dalam sistem pendidikan nasional. Aktualisasi PP No.55 tahun 2007 ke depan akan menunjukkan bagian integral dari sistem pendidikan nasional. Peraturan ini menjadi tonggak penting politik pendidikan 
yang menghapus diskriminasi antara sekolah negeri dan swasta serta sekolah umum dan sekolah keagamaan. Mengkaji lebih rinci terhadap isi PP 552007 khususnya keberadaan pesantren. Pesantren merupakan salah satu lembaga pendidikan keagamaan, lebih khususnya lembaga pendidikan keagamaan Islam yang mendaptkan legitimasi hukum dengan bergulirnya PP ini. Secara umum, beberapa fungsi yang bisa dilihat melalui pasal-pasal yang tertera dalam PP ini terhadap pengembangan pesantren ke depan diantaranya:

a. Kesempatan Mendapatkan bantuan Sama Seperti Lembaga Pendidikan Lain.

PP 55 2007, Pasal 12 ayat 1, yang isinya adalah Pemerintah dan atau pemerintah daerah memberi bantuan sumber daya pendidikan kepada pendidikan keagamaan".Penjelasan dari pasal ini adalah, "Pemberian bantuan sumber daya pendidikan meliputi pendidik, tenaga kependidikan, dana, serta sarana dan prasarana pendidikan lainnya. Pemberian bantuan disalurkan secara adil kepada seluruh pendidikan keagamaan pada semua jalur, jenjang dan jenis pendidikan yang diselenggarakan oleh Pemerintah, pemerintah daerah, dan/atau masyarakat. Bantuan dana pendidikan menggunakan satuan dan mata anggaran yang berlaku pada jenis pendidikan lain sesuai peraturan perundangundangan".

Ke depan posisi pesantren akan berdiri sejajar dengan lembaga pendidikan lain. Tidak ada alasan untuk menganak tirikan pesantren lagi. Hak yang akan didapat pesantren dari pemerintah terutama dalam hal finansial akan sama seperti hak yang didapat oleh pendidikan umum. Terlepas apakah hak finasial itu dari pemerintah daerah, provinsi maupun pemerintah pusat.

Empat unsur penting isi dari rekomendasi pasal di atas, yang kemungkinan akan terberdayakan, diantaranya adalah unsur Pendidik, Tenaga Pendidikan, dana, dan Sarana prasarana 
b. Pelajar di pesantren memiliki kesederajatan yang sama dengan pelajar di lembaga pendidikan lainnya

Pengakuan yang sama oleh pemerintah dalam dunia pendidikan terhadap pelajar di pesantren dengan pelajar di lembaga pendidikan lainnya, sebagaimana tertuang dalam pasal 11 ayat 1,2 , dan $3^{24}$. Pernyataan yang tertera pada pasal 11 ayat 1 sampai 3 merupakan peluang emas bagi santri di kalangan Pondok pesantren untuk bisa berinteraksi dan bersinergi atau bahkan berkompetisi dengan pelajar dari lembaga pendidikan lain secara sehat dan terbuka. Tiga point penting yang mengangkat posisi santri menjadi sederajat dengan kalangan pelajar yang lain adalah : 1) Santri yang sedang menempuh sekolah di pesantren bisa pindah ke lembaga pendidikan lain yang sejenjang. 2) Lulusan pesantren ke depan juga bisa melanjutkan pendidikan ke jenjang di atasnya di luar lembaga pendidikan pesantren dengan status sah dan diakui oleh pemerintah. 3) Adanya kemungkinan out put lulusan pesantren ke depan mempunyai hak yang sama untuk merebut dan bersaing untuk bisa mendapatkan pekerjaan yang layak. Termasuk berebut menjadi abdi negara di lingkungan lembaga dan kedinasan milik pemerintah.

c. Pendidik lulusan dari pesantren medapatkan pengakuan yang sama

Pengakuan yang sama antara pendidik yang merupakan lulusan pesantren dengan di lembaga lain, diatur sesuai dengan Pasal 26. Pada pasal 26 ayat1, 2 dan 3 PP Nomor 55 Tahun 2007 menjelaskan secara rinci tentang pesantren, dan memberikan legitimasi yuridis terhadap eksistensi pesantren ${ }^{25}$.

Pada pasal 26 Ayat 3, bahwa peserta didik dan atau pendidik memperoleh pengakuan yang sama meskipun tidak memilki ijazah pendidikan formal, setelah melalui uji kompetensi

${ }^{24}$ Pasal 11 ayat 1, 2 dan 3 , PP No.55 tahun 2007 tentang Pendidikan Agama dan Pendidikan Keagamaan

${ }^{25}$ Pasal 26 ayat 1, 2 dan 3 PP 55 tahun 2007 
sesuai dengan ketentuan peraturan perundang-undangan. Ayat ini memberikan pengakuan terhadap alumni pesantren untuk menjadi pendidik dalam mengajarkan ilmu agama pada semua jalur, jenjang dan jenis pendidikan setelah mendapat pengakuan harus melalui uji kompetensi yang sesuai dengan ketentuan yang berlaku. Pengakuan terhadap ini tentu harus melalui pengakuan surat bukti menamatkan pendidikan di pondok pesantren atau ijazah/syahadah, jika ijazah yang dikeluarkan pesantren tidak mendapatkan pengakuan, tentu ayat 3 PP nomor 55 Tahun 2007 hanya ada dalam aturan tetapi tidak aplikatif.

Oleh karena itu, Direktorat Jenderal Kelembagaan Islam mengeluarkansuratedaran tentang legalisasi Ijazah pesantren. Surat Direktur Jenderal Kelembagaan Agama Islam Departemen Agama RI Nomor : Dj.II.II/V/PP.00.7/AZ/28/04 tanggal 9 Januari 2004, dan Nomor DJ.I/PP.00.7/940/2008 tanggal 29 Juli 2008 tentang Penyetaraan Lulusan Pondok Pesantren dan Pendidikan Diniyah.Salah satu butir isi surat edaran ini adalah tentang mata pelajaran yang harus dipenuhi pesantren agar ijazah lembaga pendidikan ini diakui keabsahannya.Surat edaran ini menjadi petunjuk teknis (juknis) bagi pesantren tentang tatacara pemberian sertifikat/ijazah bagi para santri yang telah menamatkan pendidikannya di pesantren. Mata Pelajaran yang harus dipenuhi pesantren untuk legalisasi ijazah, yaitu tingkat Ibtidaiyah meliputi: Al-Qur'an, Tauhid, Fiqih, Akhlak, Nahwu, Sharaf, serta Pelajaran pendukung lain. Tingkat Tsanawiyah meliputi: Al-Qur'an, Tauhid, Fiqih, Akhlak, Nahwu, Sharaf, Tarikh, Tajwid, serta Pelajaran pendukung lain. Tingkat Aliyah meliputi Tafsir, Ilmu Tafsir, Hadis, Ilmu Hadis, Fiqih, Ushul Fiqih, Tauhid, Nahwu, Sharaf, Tarikh, Balaghah, serta Pelajaran pendukung lain. ${ }^{26}$

Melalui PP ini diharapkan sinergi antara pelajar di pesantren dengan di luar pesantren-pun akan tercipta, karena

${ }^{26}$ Muh.Idris Usman, Pesantren Sebagai Lembaga Pendidikan Islam, Jurnal Al Hikmah, tahun 2013 Vol.XIV , No.1, hlm.112. 
lulusan pesantren yang layak juga bisa mengajar di lembaga pendidikan luar pesantren. Tentu begitu juga sebaliknya. Ada simbiosis mutualisme, saling mengisi beberapa kekurangan yang ada dan saling berbagi kelebihan yang dimiliki masing-masing pihak. Hal ini merupakanwujud dari pola managerial yang baik, dengan bangunan sistem yang menciptakan begitu pentingnya arti kebersamaan. Dikotomi dan ego dari masing-masing model kelembagaan pendidikan yang ada, besar kemungkinan ke depan juga akan terminimalisir.

d. Karakter \& kekhasan ciri pesantren akan tetap dijaga.

Tentang jaminan penjagaan dan perlindungan terhadap karakter dan ciri khas pesantren tertuang didalam pasal 12 ayat 2 yang berisikan : "Pemerintah melindungi kemandirian dan kekhasan pendidikan keagamaan selama tidak bertentangan dengan tujuan pendidikan nasional". Ayat 3 "Pemerintah dan atau lembaga mandiri yang berwenang, melakukan akreditasi atas pendidikan keagamaan untuk penjaminan dan pengendalian mutu pendidikan sesuai Standar Nasional Pendidikan. Ayat 4"Akreditasi atas pendidikan keagamaan sebagaimana dimaksud pada ayat (3) dilaksanakan setelah memperoleh pertimbangan dari Menteri Agama”.

Dari pasal ini kita harapkan akan menghapus Kekhawatiran banyak tokoh yang pesimis akan disahkannya PP 552007 ini, bakal akan mereduksi karakter dan ciri khas pesantren akan terjawab oleh isi pasal 12 ini, yang menyuratkan perlindungan penuh dari pemerintah. Melihat pelaksanaan pendidikan pesantren selama ini, hal-hal yang prinsipil-pun tidak ada yang bertentangan dengan produk hukum pemerintah apapun namanya. Bahkan berjalan seiring dengan tujuan suci pendidikan nasional kita. Kalaupun ada sedikit pergeseran itu wajar, sebagai konsekwensi logis dari perberlakuan peraturan baru. Dan pergeseran itupun menjadi keniscayaan sebagai upaya perbaikan model pendidikan pesantren agar tidak stagnan - itu-itu saja - yang terkesan jalan di tempat. Tuntutan zaman saat ini-pun sepertinya meminta agar pesantren 
beserta lulusannya bisa berdiri sejajar dengan lulusan darilembaga pendidikan lainnya.

e. Menjanjikan terjadinya harmonisasi antar pelajar lintas pemeluk agama

Sikap optimisme akan terjalinnya hubungan yang harmonis antar pelajar lintas agama ke depan, tertuang pada pasal 5 ayat 3 sampai 6 tertera didalamnya "Pendidikan agama mendorong peserta didik untuk taat menjalankan ajaran agamanya dalam kehidupan sehari-hari dan menjadikan agama sebagai landasan etika dan moral dalam kehidupan pribadi, berkeluarga, bermasyarakat, berbangsa, dan bernegara". Ayat 4 "Pendidikan agama mewujudkan keharmonisan, kerukunan, dan rasa hormat diantara sesama pemeluk agama yang dianut dan terhadap pemeluk agama lain".Ayat 5 "Pendidikan agama membangun sikap mental peserta didik untuk bersikap dan berperilaku jujur, amanah, disiplin, bekerja keras, mandiri, percaya diri, kompetitif, kooperatif, tulus, dan bertanggung jawab. Ayat 6. "Pendidikan agama menumbuhkan sikap kritis, inovatif, dan dinamis, sehingga menjadi pendorong peserta didik untuk memiliki kompetensi dalam bidang ilmu pengetahuan, teknologi, seni, dan/atau olahraga".

Pembangunan mental sebenarnya adalah hal terpenting dari tujuan pendidikan. Nabi Muhammad SAW pun diutus untuk menyempurnakan akhlak ummatnya. Kesempurnaana akhlak akan tercipta bila mempunyai kecerdasan mental. Beberapa bukti riil cerdas secara mental adalah mempunyai sikap berperilaku jujur, amanah, disiplin, bekerja keras, mandiri, percaya diri, kompetitif, kooperatif, tulus, dan bertanggung jawab. Dan bukti tertinggi adalah bisa menjalin hubungan harmonis dengan orang lain. Terlepas apakah mereka itu pemeluk satu agama atau pemeluk agama lain. Dengan harmonisasi hubungan, kedamaian akan tercipta. Suatu keadaan yang pasti diinginkan oleh semua orang. Semuanya akan terasa indah dengan kedamaian. Sekaligus hal 
ini akan menepis klaim dan opini selama ini, yang menganggap pesantren sebagai sarang teroris.

Demikian, beberapa point yang dapat dijadikan sebagai fungsi dikeluarkannya PP 55 tahun 2007 khususnya bagi pengembangan pesantren ke depan. Pesantren memperoleh kesetaraan dalam hal memperoleh dana, pelajar, pendidik, terjaminnya kekhasan pesantren, dan harmonisasi antar umat beragama. Fungsi-fungsi tersebut diharapkan tidak hanya menjadi suatu fungsi yang hanya tersurat dalam peraturan, akan tetapi juga aplikatif dalam pelaksanaannya. Sehingga keberadaan PP ini benar-benar akan membawa manfaat, khususnya di sini dalam pengembangan pesantren.

\section{Saran Kebijakan}

a. Pemerintah hendaknya memberikan kesempatan yang sama kepada kepada pesantren sebagai lembaga pendidikan. Misalnya kesempatan untuk mendapatkan bantuan dana pendidikan(Pasal 12 PP No.55 Tahun 2007) seperti lembaga pendidikan lainnya. Karena pesantren telah membuktikan eksistensinya sebagai lembaga pendidikan yang tidak bisa dipandang sebelah mata bagi keberhasilan dunia pendidikan di Indonesia.

b. Pemerintah hendaknya melaksanakan amanah sebagaimana tertulis dalam peraturan, bahwa akan menjamin karakter dan kekhasan ciri pesantren sebagaimana pasal 12 ayat 2 PP Nomor 55 tahun 2007

c. Pesantren hendaknya bersikapterbuka menerima segala perbedaan, perubahan, dan kelemahan terutama tentang manajemen pesantrennya untuk dicarikan solusinya sehingga tetap bisa eksis dan survive menghadapi tantangan zaman.

d. Pemerintah dan Pesantren untuk menelaah lebih lanjut tentang pendidikan berbasis masyarakat. Sehingga 
pendidikan dari, oleh dan untuk masyarakat bisa terwujud optimal.

\section{Simpulan}

pendidikan berbasis masyarakat secara konseptual, adalah model penyelenggaraan pendidikan yang bertumpu pada prinsip "dari masyarakat, oleh masyarakat dan untuk masyarakat". Pesantren sebagai lembaga pendidikan keagamaan Islam berbasis masyarakat, dimana pesantren dengan kekhasan dan kemandirian penyelenggaraan, pengelolaannya sehingga tetap survive dalam kehidupan bermasyarakat. Analisis tentang pesantren sebagai lembaga pendidikan keagamaan Islam berbasis masyarakat, jika ditinjau dari: segi hukum, agama, politik, pendidikan, sosial dan budaya. Beberapa point yang dapat dijadikan sebagai fungsi dikeluarkannya PP 55 tahun 2007 ini. Pesantren memperoleh kesetaraan dalam hal memperoleh dana, pelajar, sebagai pendidik, terjaminnya kekhasan pesantren, dan harmonisasi antar umat beragama. 
Pesantren: Lembaga Pendidikan Berbasis Masyarakat....

\section{DAFTAR PUSTAKA}

Ahmad Ali Riyadi, Pesantren dalam bingkai Politik Birokrasi Pendidikan Islam di Indonesia, Vol.23 No.1 Januari 2012

AminHaedari, dkk, Masa Depan Pesantren, Jakarta: IRD PRESS, 2004

Azyumardi Azra, Esei-Esei Inteletual Muslim Pendidikan Islam, Jakarta:Logos Wacana Ilmu,1998

Depag RI, Pondok Pesantren dan Madrasah Diniyah perttumbuban dan perkembangannya, Jakarta: Depag RI, 2003

Isjoni, Pendidikan sebagai Investasi Masa Depan, Jakarta: Yayasan Obor Indonesia,2006

Manfred Open dan Wolfgang Karcher, Dinamika Pesantren, Jakarta:P3M,1988

Muh.Idris Usman, Pesantren Sebagai Lembaga Pendidikan Islam, Jurnal Al Hikmah, Vol.XIV , No.1, 2013

MujamilQomar, Pesantren dari Transformasi Metodologi Menuju Demokratisasi Institusi, Jakarta: Erlangga, 2006

NourouzzamanShiddiqi, Jeram-jeram Peradaban Muslim,( Yogyakarta:Pustaka Pelajar,1996)

NurcholishMadjid, Bilik-Bilik Pesantren sebuah Potret Perjalanan, Jakarta: Paramadina,1997

Nurotun Mumtahanah, Pengembangan Sistem Pesantren dalam Meningkatkan Profesionalisme Santri, Al-Hikmah Jurnal Studi Keislaman,Vol.5(1)2015

PMA Nomor 3 Tahun 2012 Tentang Pendidikan Keagamaan Islam

PP Nomor 55 Tahun 2007 tentang Pendidikan Agama dan Pendidikan Keagamaan 
Sam M.Chan, Tuti T. Sam, Analisi SWOT: Kebijakan Pendidikan Era Otonomi Daerah, Jakarta: PT RajaGrafindo Persada, 2007

Suwendi, Penguatan Peran Pesantren, 15 Maret 2017, http://www. nu.or.id/post/read/76057/penguatan-peran-pesantren, di akses pada november 2017 pukul 09.00

Toto Suharto, Pesantren Persatuan Islam(1987-1997) dalam perspektif Pendidikan Berbasis Masyarakat,Disertasi,Yogyakarta: PPs UIN SUKA,2011

UU guru dan Dosen dan UU SISDIKNAS ( Sistem Pendidikan Nasional) UU RI No. 20 Th.2003, Jakarta: Asa Mandiri

Zubaedi, Pemberdayaan Masyarakat berbasis Pesantren, Yogyakarta: pustaka Pelajar, 2009 